\title{
Learning from Problem-Based Projects in Cross-Disciplinary Student Teams
}

\author{
Pål Ellingsen ${ }^{1, *}$, Trude Tonholm ${ }^{1}$, Frode Ramstad Johansen ${ }^{2} \mathbb{D}$ and Gunnar Andersson ${ }^{2}$ (D) \\ 1 Faculty of Health and Welfare, Østfold University College, 1757 Halden, Norway; trude.tonholm@hiof.no \\ 2 Faculty of Engineering, Østfold University College, 1757 Halden, Norway; frode.r.johansen@hiof.no (F.R.J.); \\ gunnar.andersson@hiof.no (G.A.) \\ * Correspondence: pal.ellingsen@hiof.no
}

Citation: Ellingsen, P.; Tonholm, T.;

Johansen, F.R.; Andersson, G.

Learning from Problem-Based

Projects in Cross-Disciplinary Student

Teams. Educ. Sci. 2021, 11, 259.

https://doi.org/10.3390/

educsci11060259

Academic Editor: Robyn M. Gillies

Received: 31 March 2021

Accepted: 20 May 2021

Published: 26 May 2021

Publisher's Note: MDPI stays neutral with regard to jurisdictional claims in published maps and institutional affiliations.

Copyright: (c) 2021 by the authors. Licensee MDPI, Basel, Switzerland. This article is an open access article distributed under the terms and conditions of the Creative Commons Attribution (CC BY) license (https:// creativecommons.org/licenses/by/ $4.0 /)$.

\begin{abstract}
This paper explores how Engineering students and Work and Welfare students reflect upon their own engagement in a one-week cross-disciplinary project. To develop a better understanding of what unfolds during these activities we collected data through anonymous surveys two consecutive years. Data from these 141 respondents were analysed using a learning history approach and are presented as narratives. Results show major disruptions and conflicts driving the student projects, exposing inviting confrontations, social identity threats, managing diversity, and friction of ideas. Whereas this in many cases led to new and better project solutions, these real-world experiences raise awareness of the need for tools and methods for training students. The aim of the paper is to learn from students' experiences through narrative distance, and fill a gap in the literature between problem-based learning (PBL) and the learning history method. Discussing different experiences of cross-disciplinary teamwork through the explanations of these theories, we also lay out potential questions for future research on the topic.
\end{abstract}

Keywords: cross-disciplinary student teams; conflicts; stereotypes; leadership; friction of ideas; problem-based projects

\section{Introduction}

Each year students at Østfold University College in Norway participate in a social innovation project. The students come from the programmes Innovation and Project Management at Faculty of Engineering ("IPL" students), and Work and Welfare at Faculty of Health and Welfare ("AVF" students). This learning project is open, where interdisciplinary teams decide target groups, aims, ideation and prioritization of ideas, develop a solution, and finally present their concept in a competition with minimal tutoring from staff.

The aim is problem-based learning (PBL) in cross-disciplinary teams, unfolding narratives according to different parties' perspectives. This cooperative perspective on PBL, based on Vygotsky's social development theory [1], individuals depend on their group to achieve common goals, and learning is achieved through collaboration, interaction, and shared understanding [2]. According to Schmidt, van der Molen, Te Winkel and Wiljnen [3], PBL is understood as a constructivist approach to learning, and as a learning-to-learn process. Generally, PBL has six defining characteristics: (1). The use of problems as the starting point for learning, (2). Small-group collaboration, (3). Flexible guidance of a tutor. Because problems steer the learning in such curriculum, (4). Numbers of lectures are limited, (5). Learning is to be student-initiated and finally, (6). Ample time for self-study should be available [3] (p. 228). Students have to organize learning both individually and in groups, including management of time and information [3]. PBL works best when students and tutors understand the various factors that influence learning and are aware of their roles [4] (p. 1). One key factor that can influence success is student motivation for PBL and how they respond to being immersed in the process [4] (p. 3). The problem comes first in PBL and needs to be explained in terms of a theory, an underlying principle, process, 
or mechanism [3] (p. 228). In this article, we use a narrative history approach. Narrative distance is defined as the cognitive or emotional space afforded by indirect communication that invites listeners to make sense of content [5]. Through this article we also want to: (1) Create a narrative distance to the learning histories presented; (2) Through narrative distance support transformative learning experiences [6]. In this regard, this article invites the readers to draw conclusions for themselves and use the narratives to support learning [6]. The readers must in other words interpret the meaning of the narrative for themselves since they are about the students and their learning histories. The narrative distance, emotional or cognitive, allows the readers to decide how they will make sense of the content of the narrative [7].

Gilbert [8] reports frequent use of interdisciplinary programs engaging social work students with different disciplines, but a noticeable lack of collaboration between social work and engineering disciplines. Digital solutions in particular, and re-thinking social work in general, demands knowledge of how such collaborative work is experienced.

IPL students employ teamwork as their standard method of work, whereas AVF students use individual study methods with less teamwork. This project occurs in IPLs' first and AVFs' third year, but it is the first interdisciplinary project for both classes. The collaborative focus is two-dimensional-one being to collaborate with other students in general, the other to collaborate with students from a different unit, in this case even a different faculty. The first-year IPL students are early in their discipline-specific education, and the implications of this must be considered regarding the assumption of the teams being truly cross-disciplinary. One major implication is that a student's development of their professional identity affects their own well-being, and the relationships they form with fellow students [9]. Monrouxe [9] (p. 40) describes professional identities as "contested and accepted through synergistic internal-external process of identification that is constituted in and through language and artefacts within specific institutional sites". The students' learning histories can provide better insights into how we might develop their learning experiences, facilitating their development of a professional identity [9].

The aim of this paper is to learn from students' experiences and fill a gap in the literature between PBL and the learning history method, unfolding narratives according to different participants. The research question is the following: How do interdisciplinary teams affect problem-based projects?

\section{Materials and Methods}

This study employs the learning history method [10-14] as format for distributing students' experiences from the project. Learning history is both process and result, and includes individual, organizational, and project feedback loops.

This method can help organizations increase awareness of their own learning and stimulate dissemination of these in the contributing organizations. "The virtue of the learning history text is that it provides a common experience that can be discussed and assessed at different times and places" [14].

The learning history method is anchored in organizational development and the cogenerative model emphasizing participation, creating arenas for communication, reflection, practices, and actionable knowledge [15]. It is a retrospective account of practices and events and understood in itself as an arena for reflection and learning, or may be read and interpreted in an iterative process.

Four elements combined form the basic design criteria [14] for this research methodology:

(1) Multi-stakeholder co-design around notable accomplishments;

(2) Insider/outsider teams leading reflective interviews;

(3) Distillation and thematic writing;

(4) Validation and diffusion with original participants and salient others. 
The project learning history is written in a unique structured format (see Chapter 3 Results), pairing participant statements and researcher interpretations of the statements, unfolding narratives according to different voices in the project [12].

Most noticeable in the format is the jointly told story in the two-column format linking interpretations and comments with the participants narratives. Except for this, the method has a lot in common with other types of qualitative data analysis, which gave us researchers common grounds for collaboration on this particular study. Our analysis combines the learning history format with traditional thematic analysis [16] to make a coherent approach and include all four academic disciplines represented by the authors (physics, engineering, social work, and sociology).

The project has been going on for several years, with systematic evaluation conducted during the last two. Each student in the twelve cross-disciplinary teams of third year AVF students and first year IPL students was sent a questionnaire ( $N=197)$, collecting 141 answers (year one-55 of 96, year two-89 of 101). Our interest are solely their experiences told through the stories, so the answers distributed among the researchers were anonymous. In accordance with the provisions of the Personal Data Act and the Norwegian Social Science Data Services (NSD) gender, age, programme, or other characteristics are not collected.

All students were requested to participate in the study by e-mail, but it was made clear this was voluntary, hence some are missing from the total number of students. The survey had three open questions:

(1) What have you done in the project?

(2) What have you understood from the experiences?

(3) What is your next step to explore the issues?

The open-ended rich text format allowed for respondents' reflections on the different questions, so the data are more qualitative than quantitative, hence our line of analysis. SurveyXact was used for the data collection to keep it anonymous - this is an online system allowing for anonymous respondents and rich text format narratives suitable for our research design.

Participating student are all speakers of Norwegian or other Scandinavian languages, therefore, the survey was in Norwegian and so were the initial analysis and discussion among the authors. Each author translated data used in different analyses and produced the different tables of learning histories, thus, these are not necessarily coherent in style. This, to reflect the original material behind each section and giving the readers an opportunity for a wider interpretation of the stories, is in line with the concept of learning history as a method.

A first reading and sorting of all data through a simple coding process, marking the recurring themes in the texts, was conducted by each researcher individually, before meeting up for a collaborative analysis and initial discussion. In this first joint meeting, to be able to utilize the research group's interdisciplinary composition, we opted for the solution of each researcher cutting their further line of inquiry down to one, and only one theme. Keeping within our common focus of "student experiences", the choice had to be evident and clearly recognized in the materials for all authors, although we allowed for theoretical explanations from the suggesting researcher. This resulted in four theoretical approaches: inviting confrontations, social identity threats, managing diversity, and friction of ideas.

Based on this reduction, each author further explored their chosen area of inquiry and conducted further analysis, combining theory and learning histories, before we again met up to combine these into a unifying discussion. Combining the different theoretical approaches helped us see new meaning in our own analysis, and reconsider interpretations of quotes in a way that enriched our own discussion.

Multiple investigators and transparent data provided reliability and validity for the study [12,14]. In the Field Manual for a Learning Historian, Kleiner and Roth [12] recommend developing reliability and validity in keeping the material grounded in the data through 
research. In a learning history, this process is transparent in the jointly told narrative in the two-column format linking interpretations, comments and questions with the participants narratives from the open-ended survey feedback. We included participating teachers from the involved faculties in the validation. We did not include the students for further validation of the complete learning history, because of practical difficulties due to the time gap between the actual workshop and the learning history distillation.

\section{Results}

The narrative highlights and discusses cross-disciplinary teams along four axes: inviting confrontations, social identity threats, managing diversity and friction of ideas. Managing social relations is hard work, and with the added pressure of prestige or competition managing roles, personalities and tasks, it often ends up more like noise than "jamming". Regardless of the form of management, findings indicate that active management of the group and active self-management of the individual are drivers of each other that positively influence the ability of the group to innovate. "The inertia of social life" or the resistance to change, through habits, routines, and institutionalization, hamper students' learning. The friction created in the meeting of ideas from different scholarly positions, first-year team-leaders who is early in their discipline specific education and leaders of third-year students, all contributes to change, but also to confrontations.

\subsection{Inviting Confrontations}

Problem-based projects in cross-disciplinary teams introduces interdependency of work, a blurred line of command, lack of knowledge (of parts), incompetence (experienced), and decentralization, all elements challenging a student's position and perspective. The social innovation project thus invites confrontations and conflicts. Inviting confrontations are understood as a way of identifying different interests and perspectives in the teams, and the rationale is that it is possible to engage in productive dialogue about these differences. A conflict is thus not only understood as a threat for the team, but also a potential source of positive development and learning, and the theme of this chapter [17,18].

How can students work together in cross-disciplinary teams? How do they handle differences in interests? Will they try to avoid, smooth over, use power, compromise, or collaborate to handle conflicts [17]? These projects can stimulate a variety of "them and us" with low trust relations [19], but it can also cause reflection upon the meeting of different professions, position, perspectives and work practices in "productive conflicts". Examples is shown in Table 1 below.

Table 1. Learning history for conflicts.

\begin{tabular}{ll}
\hline \multicolumn{1}{c}{ The Narrative } & \multicolumn{1}{c}{ Quotes } \\
\hline $\begin{array}{l}\text { Meeting a fundamentally } \\
\text { different perspective on } \\
\text { development and } \\
\text { developing }\end{array}$ & $\begin{array}{l}\text { "We in IPL are often focused on developing innovative stuff, but I } \\
\text { do not have the knowledge about how things act out. They had } \\
\text { interests in how to act according to the regulations. They were } \\
\text { very realistic in their mindset and not so wild, that meant that we } \\
\text { together developed a rational idea that actually is doable." }\end{array}$ \\
\hline $\begin{array}{l}\text { Sharing methods and } \\
\text { techniques }\end{array}$ & $\begin{array}{l}\text { methods of the social welfare students." } \\
\text { "We used several methods I contributed to. The methods included } \\
\text { Pugh-matrixes, Thinking Hats, and Business Model Canvas." }\end{array}$ \\
\hline
\end{tabular}


Table 1. Cont.

\begin{tabular}{|c|c|}
\hline The Narrative & Quotes \\
\hline $\begin{array}{l}\text { Increasing awareness of own } \\
\text { and other perspectives and } \\
\text { work strategies }\end{array}$ & $\begin{array}{l}\text { "It has been a fulfilling project because I learned a lot, both on } \\
\text { how I work and how others work." } \\
\text { "I have also recognised that it is not always easy to understand } \\
\text { each other's ideas and opinions when you are used to work in } \\
\text { different ways." }\end{array}$ \\
\hline $\begin{array}{l}\text { Seeing the potential and } \\
\text { value in working with other } \\
\text { knowledge discourses and } \\
\text { work strategies }\end{array}$ & $\begin{array}{l}\text { "A cross-disciplinary team has its strengths and weaknesses that } \\
\text { may create conflicts / tensions, but also good ideas when it comes } \\
\text { to innovation. I experienced that the students from the other } \\
\text { study program had knowledge on topics we did not have and } \\
\text { vice versa, and we thus complemented each other." } \\
\text { "I took part in the initial phase when we did a SWOT of the team, } \\
\text { in part for the mapping but also for getting to know each other. } \\
\text { Then we moved forward in planning using a gameplan. I turned } \\
\text { out that we had learnt different use of the same method! Cool! } \\
\text { Then we compromised, rethought the order and continued the } \\
\text { work. To identify the target group the social welfare students } \\
\text { listed different social groups. Then we voted. And brainstormed } \\
\text { known challenges for the different groups. Very informative to } \\
\text { work cross-disciplinarily. In part cognitively, but also regarding } \\
\text { how to work, since we have different ways of working." }\end{array}$ \\
\hline $\begin{array}{l}\text { Accepting the challenges in } \\
\text { working with different } \\
\text { perspectives. }\end{array}$ & $\begin{array}{l}\text { "I have previously gained theoretical knowledge of how such a } \\
\text { collaboration may take place in order for it to be successful, but it } \\
\text { was nevertheless an eye-opener for how difficult it can actually } \\
\text { be." } \\
\text { "Social innovation demands a lot of efforts. It is challenging to } \\
\text { assess what works and what just sounds smart. It requires us to } \\
\text { be in dialogue with those that actual knows the problem, at the } \\
\text { same time as we challenge status quo and ask uncomfortable } \\
\text { questions." }\end{array}$ \\
\hline $\begin{array}{l}\text { Mastering the meeting of } \\
\text { fundamentally different } \\
\text { perspective on shared arenas } \\
\text { in the project. }\end{array}$ & $\begin{array}{l}\text { "When everyone in the group has different backgrounds and } \\
\text { everyone has different opinions about everything, conflicts may } \\
\text { develop. But we were good at dialogue and thus talking us } \\
\text { through the problems staying focused. I have learnt that it is ok to } \\
\text { bring up "things" that bothers me with the team. As long as you } \\
\text { are factual it is ok." }\end{array}$ \\
\hline
\end{tabular}

The students tell a story of the project as an arena for meeting a fundamentally different perspective on development and developing from that of their own scholarly tradition. In sharing methods and techniques, they develop an awareness of both their own and other perspectives and work strategies. They appreciate the potential in working with other knowledge discourses and work strategies, at the same time as they acknowledge the struggles in working with different perspectives.

They also acknowledge hard work and confrontations as part of working in crossdisciplinary teams. Accepting it and linking it to prior theoretical discussions make it relevant for the project but missing this link can cause frustration. Finally, they describe dialogue and conversations as primary skills and basis for handling confrontations.

\subsection{Social Identity Threats}

Students seem to have quite strong ideas about "us" and "the others" even early on in their bachelor journey and these ideas seems quite stereotype-based according to subject or field $[20,21]$. The notion of health and welfare as "soft" or "human-minded", whereas engineering is "hard" and "technical" is well-established schemas in our culture [22-25].

Among times and places people have faced negative stereotypes about their groups ability or belonging, and because they know of prejudice or discrimination, they may 
worry it could happen to them though they might not have experienced it personally [25]. An interesting aspect of our study is that, contrary to this, our students seem unaware of their own stereotypes or how this affects collaboration. Examples is shown in Table 2 below.

Table 2. Learning history for stereotypes.

\begin{tabular}{ll}
\hline \multicolumn{1}{c}{ The Narrative } & \multicolumn{1}{c}{ Quotes } \\
\hline $\begin{array}{l}\text { IPL students see differences in wishes and } \\
\text { dreams as a consequence of field of study. }\end{array}$ & $\begin{array}{l}\text { "Us IPLs all have great wishes and dreams and } \\
\text { expect everything to be feasible" }\end{array}$ \\
\hline $\begin{array}{l}\text { AVF students' humanitarian considerations } \\
\text { make innovation more difficult. }\end{array}$ & $\begin{array}{l}\text { "The AVFs could tell us why certain things } \\
\text { where not so easy as we thought, mainly due } \\
\text { to humanitarian reasons" }\end{array}$ \\
\hline Being innovative is due to field of study. & $\begin{array}{l}\text { "IPLs are often focused on coming up with } \\
\text { innovative ideas" }\end{array}$ \\
\hline
\end{tabular}

Wanting to keep innovation in accordance with the law is due to field of study.

"AVFs were interested in how to find solutions in accordance with the law. They're very realistic in their mindset and not so wild."

\footnotetext{
"We" know better than "them" and students in "our" field of study know our "stuff" but "they" do not.
}

1st year students expected clear answers the 3rd year students could not give. The new students see this as lack of knowledge, not considering that things get more complicated as you learn more, hence fewer clear answers.

Having different points of view is mainly a problem, something that needs to be solved through specific methods.

IPL students define "work" as time spent on campus with others, and so AVFs study-habits, for instance reading at home, is not defined as "work".

IPL students see "group attendance" as the activity with highest social value, thereby defining AVF as lazy if they work alone or off-campus.
"The members from AVF had no input from their field, whereas we IPLs had quite good control in our field."

"The AVFs did not manage to explain problem areas or their knowledge of the problem areas so it was difficult for them to answer something I thought would be easy for them that they should have known. It was difficult to get specific answers on general terms and ended in a lot of independent research."

"People with a different point of view, with different "glasses" to see things, can be very demanding. Without experience in how to meet at a common ground, as we use methods to achieve, it can be almost impossible."

"It was a big gap between IPL and AVF students throughout the project. In our group the AVF-students were not used to working for more than three hours, two times a week, something they showed through their work. This is completely different in IPL-students who are used to working $6 \mathrm{~h}$ every day plus weekends and know that things take a lot of time and effort."

"But most of all there were big differences between IPL and AVF concerning attendance. AVF seemed to be used to a lot of leniency and participation varied from that part of our group."

This "stereotyped" impression of a student's behaviour, where explanatory emphasis seems to move more towards a thought of "this happens because they are taught to think or do like this in their faculty" (pointing towards institutional factors) than "this happened because he/she is like that" (pointing towards personal characteristics), shifts the focus from person to subject [26].

A goal might be to always be able to analyse behaviour in groups based on multidimensional lines of inquiry where personality traits, earlier experience or training, knowl- 
edge of the field in question, and group dynamics all come together to explain any one situation as this usually has no exact single cause $[27,28]$.

\subsection{Managing Diversity}

The social innovation project and the use of cross-disciplinary teams introduces shared arenas for conversations, reflection, and problem solving between different stakeholders. The students represent different study programs, professions, positions, perspectives, and work practices, drawing attention to the different underlying interests of the vested parties, and how the meeting between different interests plays out in the development of the project. IPL students are explicitly studying innovation and project management and leading these cross-disciplinary student teams is a part of their training. This means that IPL students are automatically assigned as team leaders, and have to lead AVF students who are generally older and more experienced.

Leadership can be seen as a specialized role that is held and exercised by a particular person, but also as a social process that is shared and practiced by several of the team members [29]. Self-management means that team members manage and monitor their own behaviour and are responsible for the decisions they make [30]. How leadership is exercised can have a major impact on the students regardless of it being a specialized role conducted by a single team member, or a collaboration between several team members. In any case, the behaviour of each individual student influences the overall performance of the team.

Leader-member exchange (LMX) is defined as a leadership practice and describes the role-making processes between a leader and individual team members and the exchange relationship between them [31]. In low-LMX relationships, there is mainly an economic exchange between leaders and team members, for example, students investing nothing more than the minimum in problem-based projects, whether that is time or effort. Low-LMX can also occur if leaders do not invest time or effort in the project. High-LMX relationships are characterized by mechanisms of reciprocity and social exchange which become effective through mutual trust and team members' feelings of being valued [31].

The role as team-leader is generally accompanied by expectations from both the leader and the participants about the degree and amount of influence a leader can exert [29]. Examples of expectations can be motivation, innovation, relationship, and competence [29]. The learning histories presented in Table 3 show how these expectations of influence affect the narratives.

In well-functioning teams generally, the combination of psychological empowerment through self-management [30] and an inspiring and motivational leadership style stimulates the innovative ability of the team members and increases the team's performance [31,32]. The learning histories from our project show the need for prominent leadership, but also how important practical projects are for leadership training. The students who express a low perceived expertise in leadership from the team leader, had to show a higher degree of self-management according to themselves for the project to succeed. On the other hand, the students who held the role of team leader felt they had to push hard for the team to perform well, but also gained knowledge and experience in working cross-disciplinarily with people from a different position, and with different knowledge and perspectives than the ones they had. The learning histories show examples of both high-LMX in terms of reciprocity and social exchange, and low-LMX in terms of effort and perceived expertise in leadership.

The stories told show the overall diversity of the teams, but also the individual differences between team members and their knowledge and experience in working interdisciplinarily. They also show the importance of managing this diversity through the social processes in the teams. The fact that IPL students are first-year students, and less "experienced" than third-year AVF students, influences the perception of the leader. An example of this is this quote: "I also felt that I had to "take over" the team-leader's role to a greater or lesser extent because the team-leader was not sufficiently prominent in his role. 
Then I had to lead the group on the right path ( ... )". This quote from an AVF student also reveals a perception of possessing knowledge the leader does not have, and is a good example of the challenges first-year students from IPL can face in their role as team leaders of third-year AVF students.

Table 3. Learning history for managing diversity.

\begin{tabular}{ll}
\hline \multicolumn{1}{c}{ The Narrative } & \multicolumn{1}{c}{ Quotes Team Members } \\
\hline $\begin{array}{l}\text { Cross-disciplinary student teams } \\
\text { need prominent leadership and } \\
\text { structure to fulfil their tasks. }\end{array}$ & $\begin{array}{l}\text { "Nevertheless, I also felt that I had to "take over" the team } \\
\text { leader's role to a greater or lesser extent because the } \\
\text { team-leader was not sufficiently prominent in his role. } \\
\text { Then I had to lead the group on the right path (... .)." }\end{array}$ \\
\hline $\begin{array}{l}\text { Multidisciplinary learning requires } \\
\text { self-management by applying } \\
\text { varied knowledge about project } \\
\text { management and leadership. }\end{array}$ & $\begin{array}{l}\text { "We must look at the problem and the solution from many } \\
\text { different angles, both through what we learn in } \\
\text { innovation and project management, but also through } \\
\text { psychology, the psychosocial factors, politics, possible } \\
\text { immigration and other elements." }\end{array}$ \\
\hline
\end{tabular}

Leadership failure of the team demands higher self-management from the students.

"I did a lot of the work that was supposed to be done by the team-leader, but that was not initiated."

\begin{tabular}{ll}
\hline \multicolumn{1}{c}{ The Narrative } & \multicolumn{1}{c}{ Quotes Team-Leaders } \\
\hline $\begin{array}{l}\text { Active self-management influences } \\
\text { the team's performance positively } \\
\text { and increases the ability } \\
\text { to innovate. }\end{array}$ & $\begin{array}{l}\text { "I have been a pusher, trying to see things from different } \\
\text { angles. Feels that I have made a positive contribution." }\end{array}$ \\
\hline $\begin{array}{l}\text { Good project management is crucial } \\
\text { for multidisciplinary learning and } \\
\text { psychological empowerment. }\end{array}$ & $\begin{array}{l}\text { "I have understood that cross-disciplinary collaboration } \\
\text { can lead to a great diversity in terms of ideas, competence } \\
\text { and what path the project can take. Good project } \\
\text { management is also crucial to the successful completion of }\end{array}$ \\
\hline & $\begin{array}{l}\text { a project." } \\
\text { "I have been a team leader, even though we all have } \\
\text { participated in the decisions relating to the project. } \\
\text { Personally, I have been involved in discussions about } \\
\text { social issues in our community as well as in society in } \\
\text { general. We studied problems in different contexts, and } \\
\text { thus gained an insight into what we can work on to try to } \\
\text { improve several aspects of society. (... ) it gave me } \\
\text { knowledge in that area, as well as knowledge and } \\
\text { experience in working cross-disciplinarily with people } \\
\text { from a different position and with different knowledge } \\
\text { and perspectives than I have." }\end{array}$ \\
\hline $\begin{array}{l}\text { Leams can be exercised as a } \\
\text { social process. }\end{array}$ &
\end{tabular}

\subsection{Friction of Ideas}

In meetings between two different knowledge traditions and cultures, "travelling ideas" [33] in the form of different or new ideas from one part meet the established ideas, or "ideas in residence" on the other side. For the students, the cross-disciplinary teams are set up as learning arenas for collective practice [15] where different ideas, understood as cultures, traditions, routines, etc., meet and collide.

When students perceive these travelling ideas as interesting, difficult, or different, there is friction resulting in the transformation of ideas on both sides. Working together, Czarniawska [34] argues, the resulting new ideas can thus be seen as a collective "act of creation". Students react to new ideas as challenging and difficult, or as interesting and positive contributions. This affects the students' own performance in the project, as new ideas can contribute to a change in the students thinking, but also in habits, routines, and the way they work. Examples is shown in Table 4 below. 
Table 4. Learning history for friction of ideas.

\begin{tabular}{ll}
\hline \multicolumn{1}{c}{ The Narrative } & \multicolumn{1}{c}{ Quotes } \\
\hline & "Adding them to another field that can give them \\
'stimulus' allowing you to come to many more, and more \\
complex solutions that can become more comprehensive, \\
oxperiencing different ideas brings \\
new knowledge for better solutions. \\
"I experienced that the students from the other study \\
program had knowledge on topics we did not have and \\
vice versa, and we thus complemented each other."
\end{tabular}

Working interdisciplinarily with students from another discipline, students tell stories about their meeting with ideas and understandings that differ from their own experiences. In these encounters, students describe how they discuss and develop common understandings that contribute to new and more complete (holistic) ideas and solutions in the project.

Students also tell of reflecting upon how the struggle with new ideas result in new and different understandings and solutions, acknowledging that this energizing clash of ideas [34] widens their own understanding.

They also acknowledge that cross-disciplinary teams result in a better understanding of the problem they are facing, and of the benefit of the other party's knowledge in the problem-solving process.

\section{Discussion}

Two areas of discussion emerge through all four axes of analysis: how do students define and understand the concepts "conflict" and "leader"? It seems these could be key concepts in understanding how they respond to the different aspects of collaboration. As mentioned, the social innovation project invites confrontation and conflict $[11,18,20,35]$ which we believe to be important in terms of learning and managing teamwork [6]. Sometimes, however, the gap between how scientists define, describe, and discuss a term differs profoundly from the students' understanding, and students do not have the same understanding between themselves either.

IPL students are early in their discipline-specific education, which affects the relationships they form with the more experienced AVF students [9]. The students' learning histories gives us insights into their learning experiences and development of a professional 
identity [9]. Starting with the term "conflict", this can be explained both by what they have learned in previous courses, as they do when they categorize each other stereotypically $[20,21]$, but also individual differences will affect the outcome of a situation as being a positive, productive conflict or a negative, destructive conflict. Each student will bring their own experience, knowledge, and response into the situation and thereby influence the team's environment. Managing social relations can be hard work, and the added pressure of prestige or competition, managing roles, personalities, and tasks, often ends up more like noise than "jamming". As tutors, we have to consider how the learning environment supports the student's development of learning, and the skills and attitudes that shape professional identity and practice $[6,9]$. PBL is student-initiated and therefore responsibilities are upon the student, but also upon tutors and faculty to support a safe learning environment.

If they see conflicting ideas in terms of "travelling ideas" [33] or ideas new to them coming from the other part, this will affect how they respond. Possibly pushing them more towards the constructive, positive, and productive outcome, as seen when friction created between the resident ideas and the travelers' ideas contributed to change. Just like the traveling ideas created uncertainty and ambiguity around the understandings, students can find it hard to accept different ways of thinking, working, or communicating. If they allow this uncertainty to overwhelm them, or, as can be seen in some cases, they are more concerned about who is right than to allow new understandings to arise, they may miss out on what could possibly be achieved through translation of ideas in interdisciplinary learning.

If the students are not aware of their own stereotypical thinking, either because they have some pre-set idea about the "others" or because they see their way as the only way, conflicts can easily result in a variety of "them and us" with low-trust relations [19]. As seen in the different study habits, some teams use these differences as a basis of learning, they allow the conflicting ideas to fuel reflections about how there might be some good in both solutions and as a team they need to find some common grounds, learning from each other and maybe experiencing something that could be useful for other circumstances. "The inertia of social life" or the resistance to change, through habits, routines, and institutionalization, hampers students' learning. The friction created in the meeting of ideas from different scholarly positions contributes to change, but only if students see friction as positive. Being aware of their own stereotypes and sharing this impression and categorization of "the others" opens up the possibilities to find new and better solutions.

Different study habits and how those are linked to value are visible in our material. IPL students' idea of being a hard-working student is connected to attendance, predominately visible and collaborative group attendance, or at least to be present on campus. AVF students have different ideas of how to be a hard-working student; their concept does not value attendance or group participation over individual studies and reading or working at home is just as good as campus attendance. This leads up to the IPL students defining AVFs as lazy, as the only work they value is what happens on campus so if a student goes home this is interpreted as not working; quote: "AVF seemed to be used to a lot of leniency and participation varied from that part of our group." Most assignments might benefit from a combination of the two strategies, and this might differ according to personal preferences. Initially discussing the pros and cons of each habit could help students understand those different ideas before negative conflicts emerge.

How students interpret differences seems to influence strongly how they handle this in the team [3]. Different points of view being handled as "problems" or something that needs to be solved is handled differently, from differences seen as productive sources of useful information. Different strategies, for instance, to avoid, smooth over, use power, compromise, or collaborate to handle "differences" [18], will affect the outcome of the ongoing project but also more general ideas about "others". Being aware of stereotypes and "othering" on a different basis may help them develop skills needed for collaborative 
work later on in their professional life. The "we know better than them" idea is usually not productive for collaborations.

Another term strongly affected by different ideas embedded in students' consciousness is the term "leader". If they understand leadership as negative "bossing" it can influence both the leader and the team [29]. The material shows both reluctance to lead, making the leaders role nearly invisible, but also reluctance to be led, making it difficult to lead. Regardless of the form of management, findings indicate that active management of the group and active self-management of the individuals are drivers of each other that positively influence the ability of the group to innovate [30].

The social innovation project and the use of cross-disciplinary teams introduces shared arenas for conversations, reflections, and problem solving between different stakeholders. The students represent different study programs, professions, positions, perspectives, and work practices, drawing attention to the different underlying interests of the vested parties, and how the meeting between different interests plays out in the development of the project. As part of their education the team leader is always a first-year student. This means they have to lead students that are generally older and more experienced, so how can this affect their choices of leadership style and strategies?

Leading a group that respects you because you are ranked higher, more experienced, or by some other criterion, requires less management skills. Leading someone who does not necessarily accept your position or comply with your "rules" requires more management skills, and so we observe a lot of different try-and-error attempts, and some frustration, throughout the projects. These observations can be seen as impacts of first-year IPL students being assigned as leaders of the teams as a part of their training. As leadership has changed over the last decades from traditional "bosses" who could, and would, enforce sanctions if employees did not obey their rules, most leaders today do not have the same means to control their staff [29]. They may have more or different education than their leaders, and fewer jobs today require set timetables for attendance. This agrees with first year IPL students leading third year AVF students.

Different strategies are necessary to make people perform under such conditions and so this project mirrors situations project managers will probably come across in their future careers. This situation generates different strategies, and we see everything from "laisses-faire" leaders who give up leading at all to "bosses" trying to make their team comply with rules they do not agree with, and so are bound to break. Those who succeed are able to embrace their team's differences, open up to discussions, and lay down a set of common rules everyone can accept. This is not to say problems will not occur even in those teams, but this can be manageable as long as the majority of team members agree and comply.

How can educators help students learn and thrive in groups or teamwork? First, we have to realize this does not happen naturally by itself. We see a lot of stress caused by educators having high expectations of positive synergies without giving students the necessary tools to succeed. Explaining and preparing them by focusing on differences as something positive, giving them a different perspective on conflicts as potentially positive and productive and tools to help them think outside their boxes might help them learn from success instead of failure [36]. Too often we comfort ourselves when students fail by repeating the old saying "they will learn from their failure", when in fact we risk hurting their self-image more than we help them learn.

Second, we need to realize the need for leadership and helping students lead adequately for different situations. This is not just to avoid negative confrontations or quarrels, but to help creativity and innovation. Research done by Ginzburg et. al [37] confirms that the greatest change in skills for students in problem-based learning programs who have focused on leadership is in thinking outside the box and process improvement. These are essential skills regarding social innovation, as well. An inspiring and motivational leadership style stimulates the innovative ability of the team members and increases the team's performance [31]. The learning histories presented show that multidisciplinary learning in 
cross-disciplinary teams expands the students' professional horizons and development of their professional identity [9].

Differences among students in uni-disciplinary groups are typically explained by differences in personalities or the student's individual characteristics. We find it interesting that the mere introduction of interdisciplinary groups brings about a shift in explanatory cause, from individual to disciplinary or from personality to stereotypical. Comments about differences or discussions were always referred to as the "Blues" or the "Reds", and other factors like gender, age, or personality were never even mentioned. Finding that students in cross-disciplinary groups explain their differences more along the lines of subject differences or different training can be positive, as it puts less stress on the individual student since their flaws then are due to their training, not their personality.

The actual terms are less relevant, but what we found interesting was how the students seem to put a lot of explanatory value on the fact that "the others" think differently or want to do things differently, not because they are different people in general, but because their studies have shaped them to think or do as they do. This sense of explaining thoughts or behaviour based on faculty and/or field affiliation strongly contrast the explanation we come across daily when the same students work in uni-disciplinary groups [32].

Labels defining stereotypes often lead to "identity threats" as they might not correspond to a person or group's self-perception. Different groups and different people respond to labels based on how they wish to be perceived and what they want to achieve [38].

The translation of ideas, together with the widening of the idea space, contribute to new and more holistic solutions in the project, but also to the learning process itself. This resonates with Darsø [39] in that innovation competence cannot be learned only through education about innovation, it needs to be developed and learned through experience in innovation. The cross-disciplinary approach points to the complexity of innovation and, for the students as actors, the possibility to enhance their ability to maneuver and create possibilities in these complex situations [40], as it motivates them for change and work readiness. Additionally, the project literature informs us that "action, as opposed to talk, is conceived as the most important and distinctive feature of a project" [41], and this suggest that projects are a good arena for students acting out a learning process.

When students acknowledge that collaboration is a skill that can be learned, that teamwork has nothing to do with who you privately like or dislike, but rather that any difference you come across can teach you something about other personalities, knowledge fields, study habits, and lots of other useful information to prepare you for further careers, they also acknowledge that hard work and confrontation are part of working in crossdisciplinary teams. They accept it and link it to prior theoretical discussions and of relevance for the project. Finally, they describe dialogue and conversations as primary skills and basis for handling confrontations.

The implications of these observations depend on our understanding of leadership and conflicts. Do we recognize conflicts as something destructive or something healthy? In the stories from the social innovation project, we hear voices describing conflicts as both a source of creative energy and learning and tensions and hardships. Conflicts produce both noises making it difficult and the positive energy of jamming. Leadership understood as managing or facilitating a process can be essential for successful teamwork, and combination of leadership and self-management can take it from chaos to constructive confrontation. Misunderstood leader interpretations on any part of the team, either "laissesfaire" or "bossing", or other inadequate leadership approaches, will confound the process. Table 5 illustrates our findings.

This model is rather simple, but it can show the different consequences we observe in teams based on their knowledge and understanding of the two concepts of "conflict" and "leader" and their ability to set this into action when faced with complex team challenges. 
Table 5. Analysis of cross-disciplinary teamwork.

\begin{tabular}{|c|c|c|c|c|}
\hline & & & \multicolumn{2}{|c|}{ Leadership } \\
\hline & & & Negative & Positive \\
\hline & & & $\begin{array}{l}\text { Leadership as } \\
\text { unnecessary or } \\
\text { "bossing" }\end{array}$ & $\begin{array}{c}\text { Leadership as } \\
\text { constructive or } \\
\text { practical organizing }\end{array}$ \\
\hline \multirow[t]{2}{*}{ 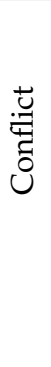 } & 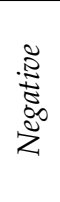 & $\begin{array}{l}\text { Conflicts as } \\
\text { something to avoid } \\
\text { and destructive for } \\
\text { progress }\end{array}$ & $\begin{array}{l}\text { Low collaboration, } \\
\text { low productivity, and } \\
\text { high levels of } \\
\text { frustration }\end{array}$ & $\begin{array}{l}\text { Low collaboration but } \\
\text { high productivity, } \\
\text { danger of jumping to } \\
\text { inadequate } \\
\text { conclusions }\end{array}$ \\
\hline & 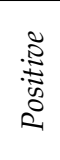 & $\begin{array}{l}\text { Conflicts as } \\
\text { productive or } \\
\text { helpful to new ideas }\end{array}$ & $\begin{array}{l}\text { High collaboration } \\
\text { but low productivity, } \\
\text { balancing not to fall } \\
\text { into frustration/stress. }\end{array}$ & $\begin{array}{l}\text { High collaboration } \\
\text { and high productivity, } \\
\text { climate for innovation } \\
\text { and growth. }\end{array}$ \\
\hline
\end{tabular}

\section{Conclusions}

Revisiting the four axes of inviting confrontations, social identity threats, managing diversity, and friction of ideas, introducing awareness and discussions on the role of conflicts and tools for handling conflicts, for example, techniques like Interest-Based Bargaining [18] and training students henceforth, is of interest. The outcome recognizes major disruptions and conflicts driving the project, exposing conflicts, stereotypes, leadership, and friction of ideas. The social innovation project is not a neutral arena, but an actor in the development of the innovation.

This study shows that students improve their individual performance, but also the cross-disciplinary teams' overall performance, when leadership skills related to teamwork, project management, self-management, social processes, and innovation is emphasized. The projects are led by first-year students and is a part of their leadership training, in which they can practice their skills as leaders of third-year students. This training contributes to the development of their professional identity in innovation and project management.

Reminding students of "group think" problems [27,28], which is why any group needs some disagreement to choose the best solution, is probably useful since engaging in groups for this purpose should be more than just coherent socializing with peers. Disruptions and hardship involved in the transitions illuminate the role of inviting confrontations. It suggests that disagreements are healthy when they act as a catalyst for change and development in social innovation.

Further, findings from this study can also indicate that successful problem-based projects in cross-disciplinary student teams are characterized by high-LMX. Regardless of the form of leadership, findings also indicate that active management of the group and active self-management of the individual are drivers of each other that positively influence the ability of the group to innovate.

Lastly, interdisciplinary work provides the students with a greater understanding of the complexity of the realisation of ideas, and in particular the human considerations from a social perspective. New ideas from people with a different viewpoint challenge the students' existing understanding, and it is perceived as demanding. The students in this project bring examples through their learning histories of how combining and challenging knowledge can help to create better solutions and narrative distance [6].

Despite or maybe because of all the aspects of inviting confrontations, social identity threats, managing diversity, and friction of ideas, working with problem-based projects in cross-disciplinary student teams makes the students understand the complexity of innovation, appreciate cross-disciplinary efforts, and motivates them for change and work readiness. For further studies, we suggest changes in students' preliminary training regarding inviting confrontations, social identity threats, managing diversity, and friction of ideas, which might contribute to exploring whether extended knowledge helps enable 
them to work and learn from teamwork, making them prepared for a cross-disciplinary work life.

Author Contributions: P.E., T.T., F.R.J. and G.A. have contributed to the article in the different stages of the work, and All authors have read and agreed to the published version of the manuscript.

Funding: This research received no external funding.

Data Availability Statement: Data is contained within the article.

Conflicts of Interest: The authors declare no conflict of interest.

\section{References}

1. Vygotskij, L.S. Mind in Society; Harvard University Press: Cambridge, MA, USA, 1978.

2. Bradshaw, M.J.; Lowenstein, A.J.; Hagler, D.A. Learning Innovative Teaching Strategies in Nursing and Related Health Professions, 8th ed.; Jones \& Bartlett: Burlington, CT, USA, 2019.

3. Schmidt, H.G.; Van Der Molen, H.T.; Te Winkel, W.W. Constructivist, Problem-Based Learning Does Work: A Meta-Analysis of Curricular Comparisons Involving a Single Medical School. Educ. Psychol. 2009, 44, 227-249. [CrossRef]

4. Bate, E.; Hommes, J.; Duvivier, R.J.; Taylor, D.C. Problem-based learning (PBL): Getting the most out of your students-Their roles and responsibilities: AMEE Guide No. 84. Med. Teach. 2013, 36, 1-12. [CrossRef]

5. Brown, J.S.; Denning, S.; Groh, K.; Prusak, L. Storytelling in Organizations: Why Storytelling Is Transforming 21st Century Organizations and Management; Butterworth-Heinemann: Burlington, MA, USA, 2004.

6. Taeger, S. Using narrative distance to invite transformative learning experiences. J. Res. Innov. Teach. Learn. 2019, 13, 211-227. [CrossRef]

7. Dettori, G.; Paiva, A. Narrative Learning in Technology-Enhanced Environments: An Introduction to Narrative Learning Environments. In Technology-Enhanced Learning: Principles and Products; Balacheff, N., Ludvigsen, S., De Jong, T., Lazonder, A., Barnes, S., Eds.; Springer: Berlin/Heidelberg, Germany, 2009; pp. 55-69. [CrossRef]

8. Gilbert, D.J. Social Work and Engineering Collaboration: Forging Innovative Global Community Development Education. J. Soc. Work Educ. 2014, 50, 292-304. [CrossRef]

9. Monrouxe, L.V. Identity, identification and medical education: Why should we care? Med. Educ. 2010, 44, 40-49. [CrossRef] [PubMed]

10. Amidon, S. The Learning History: Analyzing an Emerging Genre. J. Bus. Commun. 2008, 45, 451-482. [CrossRef]

11. Bradbury, H.; Mainemelis, C. Learning History and Organizational Praxis. J. Manag. Inq. 2001, 10, 340-357. [CrossRef]

12. Kleiner, A.; Roth, G. Field Manual for a Learning Historian; Version 4.0; MIT-COL; Massachusetts Institute of Technology: Cambridge, MA, USA, 1996.

13. Roth, G. Constructing conversations: Lessons for learning from experience. Organ. Dev. J. 2000, 18, 69-78.

14. Roth, G.; Bradbury, H. Learning History: An Action Research Practice in Support of Actionable Learning. In The SAGE Handbook of Action Research-Participative Inquiry and Practice; SAGE Publications: Thousand Oaks, CA, USA, 2008.

15. Klev, R.; Levin, M. Participative Transformation: Learning and Development in Practising Change; Routledge: Milton Park, UK, 2016.

16. Braun, V.; Clarke, V. Using thematic analysis in psychology. Qual. Res. Psychol. 2006, 3, 77-101. [CrossRef]

17. Martin, A. Interest-based bargaining: What We're Learning. Perspect. Work 1997, 1, 49-53.

18. Martin, A. Resolving workplace conflict using interest-based processes. In Participative Transformation: Learning and Development in Practising Change; Klev, R., Levin, M., Eds.; Routledge: Milton Park, UK, 2016.

19. Barrett, J.T.; O’Dowd, J. Interest-Based Bargaining: A User's Guide; OD Books: Dunshaughlin, Ireland, 2005.

20. Ashmore, R.; Del Boca, F.K. Conceptual Approaches to Stereotypes and Stereotyping. In Cognitive Processes in Stereotyping and Intergroup Behavior; Hamilton, D., Ed.; Psychology Press: London, UK, 1981; pp. 1-36.

21. Hilton, J.L.; Von Hippel, W. Stereotypes. Annu. Rev. Psychol. 1996, 47, 237-271. [CrossRef] [PubMed]

22. Bogardus, E. Stereotypes versus Sociotypes. Sociol. Soc. Res. 1950, 34, 286-291.

23. Sendén, M.G.; Eagly, A.; Sczesny, S. Of Caring Nurses and Assertive Police Officers: Social Role Information Overrides Gender Stereotypes in Linguistic Behavior. Soc. Psychol. Personal. Sci. 2019, 11, 743-751. [CrossRef]

24. Makarova, E.; Aeschlimann, B.; Herzog, W. The gender gap in STEM fields: The impact of the gender stereotype of math and science on secondary students' career aspirations. Front. Educ. 2019, 4. [CrossRef]

25. Thébaud, S.; Charles, M.J.S.S. Segregation, Stereotypes, and STEM. Soc. Sci. 2018, 7, 111. [CrossRef]

26. Steele, C.M.; Spencer, S.J.; Aronson, J. Contending with group image: The psychology of stereotype and social identity threat. In Advances in Experimental Social Psychology; Academic Press: Cambridge, MA, USA, 2002; Volume 34, pp. 379-440. [CrossRef]

27. Janis, I.L. Victims of Groupthink. In A Psychological Study of Foreign Policy Decisions and Fiascoes; Houghton Mifflin: Boston, MA, USA, 1972.

28. Janis, I.L. Groupthink. IEEE Eng. Manag. Rev. 2008, 36, 36. [CrossRef]

29. Yukl, G.; Gardner, W.L., III. Leadership in Organizations; Pearson Education: London, UK, 2020. 
30. Breevaart, K.; Bakker, A.B.; Demerouti, E. Daily self-management and employee work engagement. J. Vocat. Behav. 2014, 84, 31-38. [CrossRef]

31. Pieterse, A.N.; Knippenberg, D.V.; Schippers, M.; Staam, D. Transformational and transactional leadership and innovative behavior: The moderating role of psychological empowerment. J. Organ. Behav. 2010, 31, 609-623. [CrossRef]

32. Tummers, L.G.; Knies, E. Leadership and Meaningful Work in the Public Sector. Public Adm. Rev. 2013, 73, 859-868. [CrossRef]

33. Czarniawska, B.; Joerges, B. Translating Organizational Change; Walter de Gruyter: Berlin, Germany, 1996.

34. Czarniawska, B. A Theory of Organizing; Edward Elgar Publishing: Cheltenham, UK, 2008.

35. Røyrvik, E.A.; Bygdås, A.L. Knowledge Hyperstories-The Use of ICT Enhanced Storytelling in Organizations. In Proceedings of the Third European Conference on Organizational Knowledge, Learning and Capabilities, Athens, Greece, 5-6 April 2002.

36. Eskreis-Winkler, L.; Fishbach, A. Not Learning From Failure-The Greatest Failure of All. Psychol. Sci. 2019, 30, 1733-1744. [CrossRef] [PubMed]

37. Ginzburg, S.B.; Schwartz, J.; Gerber, R.; Deutsch, S.; Elkowitz, D.E.; Ventura-DiPersia, C.; Lim, Y.S.; Lucito, R. Assessment of medical students' leadership traits in a problem/case-based learning program. Med Educ. Online 2018, 23, 1542923. [CrossRef] [PubMed]

38. Cohen, G.L.; Purdie-Vaughns, V. An identity threat perspective on intervention. In Stereotype Threat: Theory, Process, and Application. Inzlicht, M., Schmader, T., Eds.; 2012, pp. 280-296. Available online: https:/ / oxford.universitypressscholarship.com/view / 10.1 093/acprof:oso/9780199732449.001.0001/acprof-9780199732449?rskey=qkK9kh\&result=1 (accessed on 26 May 2021).

39. Darsø, L. Innovationspædagogik; Samfundslitteratur: Frederiksberg, Denmark, 2015.

40. Johansen, F.R.; Kerndrup, S.; Andersson, G.; Rubach, S. A view of clustering as emergent and innovative processes. Ind. Innov. 2020, 27, 390-419. [CrossRef]

41. Lundin, R.A.; Söderholm, A. A theory of the temporary organization. Scand. J. Manag. 1995, 11, 437-455. [CrossRef] 